\title{
Yulafta (Avena sativa L.) çinkolu gübrelemenin verim ve verim ögeleri üzerine etkisi*
}

\author{
Nuri YILMAZ ${ }^{\circledR 1}$, Muzaffer SONKAYA ${ }^{(D 2}$ \\ ${ }^{1}$ Ordu Üniversitesi Ziraat Fakültesi Tarla Bitkileri Bölümü, Ordu \\ ${ }^{2}$ Tarım ve Orman Bakanlığı Ordu Meteoroloji Müdürlüğü, Ordu
}

*Yüksek Lisans çalışmasından alınmıştır.

Alınış tarihi: 28 Şubat 2020, Kabul tarihi: 5 Haziran 2020

Sorumlu yazar: Nuri YILMAZ, e-posta:y_nuri@hotmail.com

\section{$\ddot{0} \mathbf{z}$}

Ordu Üniversitesi Ziraat Fakültesi deneme arazisinde 2017 yılında yürütülen bu araştırmada farklı dozlarda topraktan $(0,2.5,5.0$ ve $7.5 \mathrm{~kg} / \mathrm{da})$ ve yapraktan $(\% 0,0.2$ ve 0.4$)$ çinko uygulamalarının yulafın verim ve verim ögeleri üzerine olan etkileri incelenmiştir. Materyal olarak Checota cinsi yulaf kullanılmış olup araştırma, Ordu ili ekolojik koşullarında, tesadüf bloklarında faktöriyel deneme desenine göre 3 tekerrürlü olarak yürütülmüștür. Araştırma sonucunda, çinko uygulamamlarının bitki boyu, salkım boyu, bin tane ağırlığı, ve salkımda tane ağırlı̆̆ı üzerine etkilerinin istatistiksel olarak önemli olmadığı belirlenmiştir. Buna karşılık salkımda başakçık sayısı 13.09-25.80 adet, salkımda tane sayısı 28.61-46.79 adet ve tane verimi 71.00-115.05 $\mathrm{kg} / \mathrm{da}$ arasında değişim göstemiş olup, çinko gübresinin uygulama şekilleri ve dozlarının bu ögeler üzerine istatistiksel olarak önemli etkide olduğu belirlenmiştir. Yapılan araştırmada en fazla tane verimi \% 0.4 yapraktan, $2.5 \mathrm{Zn} /$ da topraktan; \% 0.2 yapraktan, $5.0 \mathrm{~kg} / \mathrm{da}$ topraktan ve \% 0.4 yapraktan, topraktan çinko uygulamasız kombinasyonlardan elde edildiği görülmüştür.

Anahtar kelimeler: Checota, Çinko Uygulaması, Toprak, Yaprak, Yulaf.

The effect of zinc fertilizers on for some plant properties and quality characteristics on oat (Avena sativa L.)

\begin{abstract}
This study was conducted in the experimental fields of the Faculty of Agriculture of Ordu University in 2017 , the effects of zinc application from different doses of soil $(0,2.5,5.0$ and $7.5 \mathrm{~kg} / \mathrm{da})$ and leaves $(0$, 0.2 and $0.4 \%$ ) on yield and yield comonents of oats were evaluated. Checota oat cultivar were used as the material of the study and the experiment was carried out in Ordu ecological conditionswith randomized blocks according to the factorial experiment design with 3 replications. As a result of the study, the emergence time, the plant height, the panicle height, the thousand grain weight and the grain weight in panicle were not found significantly different to be statistically. On the other hand, the values were changed for the number of panicle in bunches between 13.09-25.80 units, for number of grains between 28.61-46.79 units, for grain yield between $71.00-115.05 \mathrm{~kg} / \mathrm{da}$, with the zinc treatments and they were found as significantly different. In the research, the highest grain yield was observed that it was obtained from $0.4 \%$ leaves, 2.5 $\mathrm{Zn} \mathrm{/} \mathrm{da} \mathrm{soil;} \mathrm{from} 0.2 \%$ leaves, $5.0 \mathrm{~kg} / \mathrm{da}$ soil and $0.4 \%$ leaves, soil without zinc application.
\end{abstract}

Key words: Checota, Leaf, Oat, Soil, Zinc Aplication. 


\section{Giriş}

Son beş yıllık ekim alanı ve üretim miktarı dikkate alındığında yulafın dünyadaki ekim alanı yaklaşık 1 milyon hektar azalmış, toplam üretimde ise önemli bir değişme olmamıștır. Dünyada yulaf ekiliş alanı 2017 yılında 10194793 hektar olup 25949161 ton ürün alınmış ve verim ise $254.53 \mathrm{~kg} / \mathrm{da}$ elde edilmiştir (Anonim, 2019 a). Türkiye'de ise son beş yılda yulaf ekim alanı ve üretiminde önemli bir değişme olmamakla birlikte 2017 yılında yulaf ekiliş alanı 1.128.796 dekar olup 250.000 ton ürün alınmış ve verim ise $222 \mathrm{~kg} /$ da olmuştur (Anonim, 2019 b).

Karadeniz Bölgesi ülkemiz yulaf ekim alanı bakımından \%9.8 ve üretim yönünden yaklaşık \%7'lik paya sahiptir. Karadenizin birçok ilinde yulaf tarımı yapılmaktadır. Bölgede başta Ordu olmak üzere Samsun, Çorum, Tokat, Zonguldak, Kastamonu ve Sinop illeri en fazla yulaf yetiştiriciliğinin yapıldığı yerler olup bölgenin yulaf üretim alanının \%92'sini oluştururlar. Bu illerin yulaf verimi de ülke yulaf verim ortalamasının oldukça altındadır. Bu verim düşüklüğünün en önemli nedeni bölge üreticilerinin hastalıklara hassas ve verim potansiyeli düşük yerel yulaf çeşitlerini yetiştirmesidir. Ayrıca yazlık ekim yapılması ve uygun yetiştirme tekniklerinin uygulanmaması da verim düşüklüğünün bir diğer nedenidir. Bölgede yulaf genellikle küçük tarım ișletmelerinde yapılmakta olup, üreticiler kendi hayvanlarının ihtiyacı olan yemi üretmek amacıyla yulaf tarımı yapmaktadırlar. Karadeniz bölgesi yulaf yetiştiriciliği için çok uygun ekolojiye sahip olup yapılan çalışmalar sonucunda yulaf yetiştirilen alanların arttırılmasının gerektiği ortaya koymuştur (Anonim, 2015).

2017 yılı verilerine göre ülkemizde yulaf verimi dünya ortalamasının altında olup verimin artırılmasına ihtiyaç bulunmaktadır. Yulaf veriminin ve kalitesinin arttırılması için ise uygun yetiştirme teknikleri ile uygun çeşit ve iyi tohumluk kullanılmalı, gerekli çeşit ve dozda gübre kullanımının da sağlanması, gerekmektedir. Yüksek tane verimi, yulaf çeşitlerinde en çok istenen özelliktir. Bu nedenle, yulaf çeşitlerinin tane verim potansiyeli genetik olarak arttırılmalıdır. Daha önceden yapılmış uygulamalarda, tahıl verim potansiyeli çoğunlukla tahıl verimine dayalı seleksiyon çalışmaları ile arttırılmıştır. Türkiye'deki yöresel çeşitler, yulaf gen merkezi ve genetik çalışmalarda kullanılmak üzere önemli bir potansiyel ortaya koymaktadır (Hışır ve ark., 2012).
Bitkilerin iyi bir şekilde gelişip ürün vermeleri için ihtiyaç duydukları makro ve mikro ve iz besin elementlerinin yeterli ve uygun oranlarda kök bölgesinde bulunması gerekir. Yapılan araştırmalar, bitki beslemesinde kullanılan ticari gübrelerin bilinçli bir şekilde kullanılmaları, bitki türüne ve bölgelere bağlı olarak ürün veriminde \%50-80 oranında artış meydana getirmektedir(Anonim, 2003). Yulafta kök sisteminin kuvvetli olması sebebiyle toprakta mevcut besin maddelerinden diğer buğdaygillere nazaran daha çok faydalanır. Yulafa verilecek gübre miktarı ön bitkiye, yetiştirilecek çeşide, iklim ve toprak koşullarına göre değişmektedir. Yulafın ilk gelişme dönemi ve besin maddesi alımı yavaştır, sapa kalkmayla birlikte, bitkinin tüm besin maddeleri alımı ve su tüketimi artar (Anonim, 2012).

Mikro besin elementlerinden herhangi birinin eksik ya da fazla olması bitkide olumsuz etkiler ortaya çıkartmaktadır. Mikro elementler içerisinde çinko öne çlkan bitki besin elementlerinden bir tanesidir. Çinko eksikliği altındaki bitkilerde birçok metabolik olay olumsuz yönde etkilenmektedir. Çinkonun bitkideki en önemli fonksiyonu protein sentezine doğrudan katılması ve 300'den fazla enzimin etkinliğinde doğrudan veya dolaylı olarak rol almasıdır (Coleman, 1992; Marschner, 1995; Çakmak, 2000). Bitki bünyesinde oluşan çeşitli enzim sistemleri ile sürgünlerin oluşumunu sağlayan bazı hormonların yapı taşıdır. Çinko noksanlığında bitkilerin tryptophan kapsamının azaldığı, protein sentezinin durduğu ve serbest aminoasitlerin biriktiği bilinmektedir. $\mathrm{Bu}$ durum doğal olarak ürünün nitelik ve niceliğini olumsuz yönde etkilediği söylenmektedir (Yalçın ve Usta, 1992).

Türkiye'nin tarım topraklarının \%50'sine yakını çinko bakımından fakir olduğu tespit edilmiştir (Eyüpoğlu ve ark., 1994). Dünya genelinde çinko noksanlığı, topraklarda ve bitkilerde olduğu gibi insanlarda da özellikle tahıl ürünlerine dayalı gıda tüketiminin fazla olduğu az gelişmiş veya gelişmekte olan ülkelerde yaygın bir beslenme sorunudur (Welch, 1993).

Toprak, bitki ve insan üçgeninde oluşan çinko noksanlığının giderilmesi veya azaltılmasında en hızlı ve pratik çözüm yolu bitkilerde çinkolu gübrelemedir. Çinkonun tahıllara verilmesi ile ilgili yapılan araştırmaların birçoğunda, toprağa çinko uygulamasının verim açısından daha etkili olduğu ortaya konulmuştur (Kalaycı ve ark., 1999; Özbek ve Özgümüş, 1997; Yılmaz ve ark., 1997). Çinko 
eksikliği, bitkiler ve özellikle kurak ve yarı kurak bölgelerde kalkerli topraklar üzerinde yetiștirilen tahılların veriminde ciddi düşüşler olmuştur (Graham ve ark., 1992; Kalaycı ve ark., 1999; Sönmez ve Kıral, 2004).

Bitkinin ihtiyacı olan çinkonun eksikliğinin giderilmesi veya azaltılmasında en hızlı ve kolay çözüm yolu çinko gübrelemesidir. Günümüze kadar farklı tahıl türlerinin çinko etkinlik düzeylerinin bitkisel özellikler, verim ve kalite unsurları gibi faktörlere etkisiyle ilgili birçok çalışma yapılmasına karşıllk yulaf (Avena sativa L.) ile ilgi bu niteliklerde çalışma neredeyse yok denecek kadar çok az sayıdadır. Bu nedenle yapılan çalışmayla çinkolu gübrelemenin uygun doz ve verilme şeklinin, yulafın bitkisel özelliklerine etkilerini belirlemek amaçlanmıştır.

\section{Materyal ve Yöntem}

\section{Materyal}

Araştırma 2017 yılı ilkbahar-yaz döneminde Ordu Üniversitesi Ziraat Fakültesi deneme arazisinde yürütülmüştür. Deneme arazisi Ordu ili Altınordu ilçesinde, Orta ve Doğu Karadeniz bölümünün ayrılma sınırı olan Melet nehri kiyısında yer almaktadır.

Ordu ili, Orta Karadeniz Bölgesi'nin ılıman iklim özelliklerini yansıtmaktadır. İlde yağışların büyük bir kısmı kış ve sonbaharda düşerken, özellikle yaz aylarında düşen yağışlar bitkisel üretim için yetersizdir. Yulaf yetiştirme dönemine ait uzun yıllar ortalama sıcaklık $20.6^{\circ} \mathrm{C}$, toplam yağış miktarı 259.3 $\mathrm{kg} / \mathrm{m}^{2} \mathrm{iken}$, bu değerler 2017 yılında sırasıyla $21.3^{\circ} \mathrm{C}$ ve $166.0 \mathrm{~kg} / \mathrm{m}^{2}$ olmuştur. Yetiştirme döneminde uzun yıllar nispi nem ortalaması \% 74.2 iken, 2017 yılında \% 73.5 olmuştur (Ordu Meteoroloji Müdürlüğ̈̈).

Araştırma alanından ekim öncesi 0-30 cm derinlikten 3 ayrı yerden alınan toprak örnekleri Giresun Fındık Araştırma Enstitüsünde analiz edilmiştir. Sonuçlar deneme alanı toprağının killi bünyeli, nötr (pH: 6.88), tuzsuz (toplam tuz: 0.703 $\mathrm{ds} / \mathrm{m})$, kireçli $\left(\mathrm{CaCO}_{3} \%\right.$ : 1.24), azot miktarının çok az (\%: 0.03), fosfor miktarının yeterli (P: $8.19 \mathrm{ppm}$ ), potasyum miktarının az (K: $102.0 \mathrm{ppm}$ ) ve organik maddenin az (\% 0.58), Çinko (Zn) ise az seviyede $(0,098 \mathrm{ppm})$ olduğunu göstermiștir (Bouyoucos, 1951, Richards, 1954, Hizalan ve Ünal, 1966, Maas, 1986, Nelson ve Sommers, 1982, Watanabe ve Olsen, 1965, Jackson, 1958, Lindsay ve Norvell, 1978, Bremner, 1965).
Araştırmada milli çeşitlerimizden üretim izni olan Checota cinsi tescilli yulaf kullanılmıştır. "Checota" Geçit Kuşağı (Anadolu) Tarımsal Araştırma Enstitüsünce 1986 yılında kışlık karakterde tescil ettirilmiş ve 2007 yılında tescil uzatılmıştır. Yatmaya dayanıklı, kılçıssız, bindane ağırlığı 32-33 gr, ortalama verim dekara 300-350 kg olan erkenci bir yulaf çeşididir. Tarla şartlarında pas hastalıklarına dayanıklı, rastığa orta dayanıklıdır.

\section{Yöntem}

Araştırma tesadüf bloklarında faktöriyel deneme desenine göre 3 tekerrürlü olarak kurulmuştur. Parseller 100X300 cm. ebatında olup her parsel 20 cm sıra aralıklı 5 bitki sırası içermektedir. Ekimler 3$4 \mathrm{~cm}$ derinliğe, $\mathrm{m}^{2}$ ye 500 adet tohum olacak şekilde 18 Mayıs 2017 tarihinde elle yapılmıştır. Ekimle birlikte $3 \mathrm{~kg} / \mathrm{da}$ ve salkım gösterme zamanında 3 $\mathrm{kg} / \mathrm{da}$ olacak şekilde azot $(\mathrm{N})$, ekimle birlikte 6 $\mathrm{kg} / \mathrm{da}$ fosfor (P) ve $10 \mathrm{~kg} / \mathrm{da}$ potasyum (K) verilmiştir. Araştırmada Çinko sülfat $\left(\mathrm{ZnSO}_{4}\right)$ topraktan; 0, 2.5, 5.0 ve $7.5 \mathrm{~kg} /$ da dozlarunda, yapraktan ise $\% \quad 0, \% 0.2$ ve $\% 0.4$ dozlarında uygulanmıştır. Topraktan yapılan uygulama, belirlenen dozlardaki çinko sülfat 1 lt suda çözelti haline getirildikten sonra parsellere verilmiştir. Yapraktan uygulamada ise çinko sülfat dozları $2 \mathrm{lt}$ suda çözelti haline getirildikten sonra sprey yardımıyla tüm bitkiye uygulanmıștır. Topraktan ve yapraktan yapılan çinkolu gübre uygulamaları bitkinin salkım gösterme zamanında yapılmıştır. Yabancı ot mücadelesi kontroller yapılarak gerekli olduğu zamanlarda elle yapılmıştır. Bitkiler ana saptaki danelerin sarı olum ile tam olum arasında olduğu devrede 30 Ağustos 2017 tarihinde elle biçilerek hasat edilmiştir. Hasat döneminde her parselde, parsel başlarından $50 \mathrm{~cm}$ ve parsel kenarlarında birer sıra kenar tesiri bırakılmıştır.

Araştırmada; bitki boyu $(\mathrm{cm})$, salkım boyu $(\mathrm{cm})$, salkımda başakçılk sayısı, salkımda tane sayısı, salkımda tane ağırlığı (g), bin tane ağırlığı (g) ve tane verimi $(\mathrm{kg} / \mathrm{da})$ gibi özellikler incelenmiştir. Elde edilen bulgular SAS-JMP-11.0 paket programında tesadüf bloklarında faktöriyel deneme desenine göre varyans analizi yapılmış ve önemli bulunan uygulamalar LSD testine tabi tutulmuştur.

\section{Bulgular ve Tartışma \\ Bitki Boyu}

Denemede topraktan ve yapraktan uygulanan farklı çinko dozlarının yulafın bitki boyuna etkisine ait ortalama değerler Çizelge 1 'de verilmiştir. 
Çizelge 1'de görüldüğü gibi farklı dozlarda topraktan ve yapraktan uygulanan çinko dozları ile topraktan $\mathrm{x}$ yapraktan uygulanan çinko dozları interaksiyonu'nun bitki boyu üzerine etkisi istatistiksel olarak önemli bulunmamıştır.

İstatiksel olarak önemli bulunmamakla birlikte, çalışmada bitki boyu $61.56 \mathrm{~cm}$ ile $75.81 \mathrm{~cm}$ arasında değişim göstermiştir. En uzun bitki boyu yapraktan $\% 0.2$ ve topraktan $5 \mathrm{~kg} / \mathrm{da}$ doz uygulamasından elde edilirken, en kısa bitki boyu ise yapraktan \%0.4 ve topraktan $5 \mathrm{~kg} / \mathrm{da}$ doz uygulamasindan elde edilmiştir (Çizelge 1).

Benzer şekilde, Barut ve ark., (2017) makarnalık buğday çeşitlerine çinko uygulamasının etkilerini araştırdıkları çalışmada, farklı dozlarda ve şekillerde çinko uygulamasının bitki boylarına etkisinin istatistiksel olarak önemli bulunmadığını belirtmişlerdir. Buna karşılık Öztürk, (2009) bazı kışlık yem bitkilerinde, Dülgerbaki, (2010) maş fasulyesinde ve Öktem ve ark., (2016) kırmızı mercimekte yaptıkları çalışmalarda artan çinko dozlarının bitki boyunu artırdığını belirtmişlerdir. Araștırmalar arasındaki bu farklıllkların denemelerde kullanılan genotiplerin farklı olmasıdan çevre ve uygulanan çinko dozu farklılıklarından kaynaklandığı düşünülmektedir.

Genel olarak yulaf bitkisinde, bitki boyu çevre şartlarına bağlı olarak değişmekle birlikte 70-80 cm arasında değiştiği belirtilmiştir (Anonim, 2012). Bulgularımızın bu değerler ile kısmen uyum halinde olduğu görülmüştür.

\section{Salkım Boyu}

Denemede topraktan ve yapraktan uygulanan farklı çinko dozlarının salkım boyuna etkisine ait ortalama değerler Çizelge 2'de verilmiştir.

Yapılan varyans analizi neticesinde topraktan ve yapraktan uygulanan farklı çinko dozları ile topraktan $\mathrm{x}$ yapraktan uygulanan çinko dozları interaksiyonunun salkım boyu üzerine etkisi istatistiksel olarak önemli olmamıştır.

İstatiksel olarak önemli bulunmamakla birlikte çalışmada salkım boyu $17.14 \mathrm{~cm}$ ile $21.84 \mathrm{~cm}$ arasında değişmiştir. En uzun salkım boyu yapraktan $\% 0.2$ ve topraktan $5 \mathrm{~kg} / \mathrm{da}$ doz uygulamasından elde edilirken, en kısa salkım boyu ise yapraktan $\% 0$ ve topraktan $2.5 \mathrm{~kg} / \mathrm{da}$ doz uygulamasından elde edilmiştir (Çizelge 2). Konuyla ilgili olarak Castagnara ve ark., (2012) yulafda yaptıkları çalışmada çinko uygulamalarının sap büyümesini artırdığını belirtmişlerdir. Bununla birlikte Özcan ve
Taban, (2012) ve Sonkaya, (2017) çeltik bitkisinde yaptıkları çalışmalarda, bulgularımıza benzer şekilde çinkonun salkım boyuna etkisini istatiksel olarak önemli olmadığını tespit etmişlerdir.

Çizelge 1. Çinko dozlarının yulafta bitki boyuna $(\mathrm{cm})$ etkisine ait ortalama değerler.

\begin{tabular}{cccccc}
\hline $\begin{array}{c}\text { Yapraktan Zn } \\
\text { Uygulamaları } \\
(\%)\end{array}$ & \multicolumn{5}{c}{ Topraktan Zn Uygulamaları (kg/da) } \\
\hline & 0 & 2.5 & 5 & 7.5 & Ort \\
\hline 0 & 74.17 & 63.91 & 73.02 & 66.60 & 69.43 \\
0.2 & 72.14 & 73.51 & 75.81 & 73.43 & 73.73 \\
0.4 & 70.20 & 70.61 & 61.56 & 74.69 & 69.27 \\
\hline Ortalama & 72.17 & 69.35 & 70.13 & 71.57 & \\
\hline
\end{tabular}

Çizelge 2. Çinko dozlarının yulafta salkım boyuna (cm) etkisine ait ortalama değerler

\begin{tabular}{cccccc}
\hline $\begin{array}{c}\text { Yapraktan Zn } \\
\text { Uygulamaları } \\
(\%)\end{array}$ & \multicolumn{5}{c}{ Topraktan Zn Uygulamaları (kg/da) } \\
\hline & 0 & 2.5 & 5 & 7.5 & Ort \\
\hline 0 & 20.63 & 17.14 & 19.69 & 18.78 & 19.06 \\
0.2 & 17.91 & 19.87 & 21.84 & 20.81 & 20.11 \\
0.4 & 17.44 & 18.52 & 17.30 & 20.20 & 18.44 \\
\hline Ortalama & 18.66 & 18.51 & 19.61 & 20.03 & \\
\hline
\end{tabular}

\section{Salkımda Başakçık Sayısı}

Topraktan ve yapraktan uygulanan farklı çinko dozlarının salkımda başakçık sayısına etkisine ait ortalama değerler Çizelge 3'de verilmiștir. Çizelge 3'de görüldügü gibi topraktan ve yapraktan yapılan çinko uygulamasının salkımdaki başakcık sayısına etkisinin istatistiksel olarak önemli olmadığı görülmüștür. Ancak yapraktan x topraktan uygulama interaksiyonu ise istatistiksel olarak $(p<0,05)$ anlamlı bulunmuştur. Çalışmada salkımdaki başakçık sayıları 13.09 ile 25.80 adet arasında değişiklik göstermiştir. En yüksek Salkımda başakçık sayısı topraktan $7.5 \mathrm{~kg} / \mathrm{da}$ çinko uygulaması ile \%0.4 yapraktan çinko uygulaması interaksiyonundan elde edilmiştir. Ancak yapraktan \%0.2 çinko uygulaması ile topraktan $2.5,5.0$ ve $7.5 \mathrm{~kg} / \mathrm{da}$ çinko uygulaması interaksiyonları ile aynı grubda yer almışlardır. En düşük salkımdaki başakçık sayısı ise topraktan 5 $\mathrm{kg} /$ da çinko uygulaması ile \%0.4 yapraktan çinko uygulaması interaksiyonundan elde edilmiștir (Çizelge 3).

\section{Salkımda Tane Sayısı}

Denemede topraktan ve yapraktan uygulanan farklı çinko dozlarının yulafın salkımda tane sayısına etkisine ait ortalama değerler Çizelge 4'de verilmiştir. 
Çizelge 3. Çinko dozlarının yulafta salkımdaki başakçık sayısına etkisine ait ortalama değerler.

\begin{tabular}{|c|c|c|c|c|c|}
\hline \multirow{2}{*}{$\begin{array}{c}\text { Yapraktan } \mathrm{Zn} \\
\text { Uygulamaları } \\
(\%)\end{array}$} & \multicolumn{5}{|c|}{ Topraktan Zn Uygulamaları (kg/da) } \\
\hline & 0 & 2.5 & 5 & 7.5 & Ort \\
\hline 0 & $\begin{array}{c}21.29 \\
\mathrm{abc}\end{array}$ & $\begin{array}{c}13.96 \\
\text { bc }\end{array}$ & $\begin{array}{c}20.50 \\
\text { abc }\end{array}$ & $\begin{array}{c}20.00 \\
\mathrm{abc}\end{array}$ & 18.94 \\
\hline 0.2 & $\begin{array}{c}16.24 \\
\text { bc }\end{array}$ & $24.86 \mathrm{a}$ & $25.64 \mathrm{a}$ & $25.55 \mathrm{a}$ & 23.08 \\
\hline 0.4 & $13.23 \mathrm{c}$ & $\begin{array}{c}22.25 \\
a b\end{array}$ & $13.09 \mathrm{c}$ & $25.80 \mathrm{a}$ & 18.59 \\
\hline Ortalama & 16.92 & 20.36 & 19.74 & 23.79 & \\
\hline
\end{tabular}

Çizelge 4'de görüldüğü gibi topraktan uygulanan çinko dozlarının salkımdaki tane sayısına etkisi istatistiksel olarak önemli bulunmamıștır. Fakat yapraktan uygulanan çinko dozlerının etkisi ile topraktan $\mathrm{x}$ yapraktan uygulanan çinko dozları interaksiyonunun etkisi istatistiksel olarak $(\mathrm{p}<0.05)$ önemli çıkmıştır.

Salkımda tane sayısı 28.61 ile 46.79 adet arasında değişmiş olup, en yüksek salkımda tane sayısı kontrol ile yapraktan \% 0.2 ve topraktan $7.5 \mathrm{~kg} / \mathrm{da}$ çinko uygulamasından elde edilmiştir. En düşük salkımdaki tane sayısı ise yapraktan \%0.4 çinko uygulaması ile topraktan 0 ve $5.0 \mathrm{~kg} / \mathrm{da}$ çinko uygulamalarından elde edilmiştir. Genel olarak değerlendirildiğinde topraktan uygulanan çinkonun da etkisi ile yapraktan \% 0.2 çinko uygulamasında salkımdaki tane sayısı maksimum olmuş daha sonraki dozda ise azalma olduğu görülmüştür (Çizelge 4). Konuyla ilgili olarak Yllmaz ve Sonkaya (2017), çeltikte yaptıkları çalışmada çinkolu gübrelemenin benzer șekilde belirli doza kadar salkımdaki tane sayısını artırdı̆̆ı, daha yüksek dozlarda ise azalttığını belirtmişlerdir.

\section{Salkımda Tane Ağırlı̆̆ı}

Denemede topraktan ve yapraktan uygulanan farklı çinko dozlarının yulafta salkımda tane ağırlığına etkisine ait ortalama değerler Çizelge 5 'de verilmiştir.

Yapılan analiz sonuçları değerlendirmesine göre topraktan ve yapraktan uygulanan farklı çinko dozları ile yapraktan $\mathrm{x}$ topraktan uygulanan çinko dozları interaksiyonunun salkımda tane ağırlığına etkisi istatistiksel olarak önemli bulunmamıștır.

İstatistiksel açıdan önemli olmamakla birlikte yapmış olduğumuz çalışmada salkımda tane ağırlıkları 0.40 ile 0.67 gram arasında değişim göstermiştir. En düşük salkımda tane ağırlı̆̆ı, yapraktan $\% 0$ ve topraktan $7.5 \mathrm{~kg} / \mathrm{da}$ uygulamasından elde edilirken, en fazla salkımda tane ağırlı̆̆ ise yapraktan $\% 0.2$ ve topraktan 5 $\mathrm{kg} /$ da uygulamasından elde edilmiştir (Çizelge 5).

Çizelge 4. Çinko dozların yulafta salkımdaki tane sayısına etkisine ait ortalama değerler.

\begin{tabular}{cccccc}
\hline $\begin{array}{c}\text { Yapraktan Zn } \\
\begin{array}{c}\text { Uygulamaları } \\
(\%)\end{array}\end{array}$ & \multicolumn{7}{c}{ Topraktan Zn Uygulamaları (kg/da) } \\
\hline \multicolumn{7}{c}{0} & 2.5 & 5 & 7.5 & Ort \\
\hline 0 & 46.79 & 30.29 & 37.76 & 34.85 & 37.42 \\
& $\mathrm{a}$ & $\mathrm{cd}$ & $\mathrm{abcd}$ & $\mathrm{bcd}$ & $\mathrm{AB}$ \\
0.2 & 38.0 & 43.56 & 39.75 & $46.58 \mathrm{a}$ & $41.97 \mathrm{~A}$ \\
& $\mathrm{abcd}$ & $\mathrm{ab}$ & $\mathrm{abc}$ & & \\
0.4 & 28.66 & 44.16 & $28.61 \mathrm{~d}$ & 39.15 & $35.15 \mathrm{~B}$ \\
\hline Ortalama & $\mathrm{d}$ & $\mathrm{ab}$ & $\mathrm{abc}$ & \\
\hline LSD(Yaprak): & 4.970; LSD(Yaprak x Toprak): 9.941 \\
\hline \multicolumn{7}{c}{39.34} & 35.37 & 40.19 \\
\hline
\end{tabular}

Benzer şekilde Barut ve ark., (2017) makarnalık buğday çeşitlerinde farklı dozdaki çinko uygulamalarının başaktaki tane ağrılığına etkisini; Yılmaz ve Sonkaya (2017), çeltikte yaptıkları çalışmada çinkolu gübrelemenin salkımdaki tane ağırlığına etkisinin istatistiksel açıdan anlamlı olmadığını belirtmişlerdir.

\section{Bin Tane Ağırlığı}

Denemede topraktan ve yapraktan uygulanan farklı çinko dozlarının yulafta bin tane ağırlığına etkisine ait ortalama değerler Çizelge 6'da verilmiştir.

Yapılan varyans analizi neticesinde topraktan ve yapraktan uygulanan çinko dozları ile yapraktan $\mathrm{x}$ topraktan uygulanan çinko dozları interaksiyonunun bin tane ağırlı̆̆ üzerine etkisi istatistiksel olarak önemli bulunmamıștır. İstatiksel olarak önemli bulunmamakla birlikte çalışmada bin tane ağırlığ 25.23 ile $28.04 \mathrm{gr}$ arasında değişiklik göstermiştir. En yüksek bin tane ağırlığı yapraktan $\% 0.4$ ve topraktan $2.5 \mathrm{~kg} / \mathrm{da}$ doz uygulamasından elde edilirken, en düşük bin tane ağırlığı ise yapraktan $\% 0$ ve topraktan $7.5 \mathrm{~kg} / \mathrm{da}$ doz uygulamasindan elde edilmiştir (Çizelge 6). Yapmış olduğumuz çalışmayla ilgili literatürdeki araştırma bulguları arasında farklılıklar olduğu belirlenmiştir. Çalışmamıza benzer şekilde buğdaylarda yapılan çalışmada; Sayed ve ark., (1988) çinko uygulamasının bin tane ağırlığına herhangi bir etkisinin olmadığını belirtmiştir. Öte yandan Barut ve ark., (2017); Mishra ve ark., (1989) ve Ekiz ve ark., (1998) çinko uygulamalarının bin tane ağırlığı üzerine etkisini istatistiksel olarak önemli olduğunu söylemişlerdir. Ayrıca Dülberbaki, (2010) maş fasülyesinde, Yılmaz 
ve Sonkaya, (2017) çeltikde çinko uygulamalarının 1000 tane ağırlığını azalttığını belirtmișlerdir. Araştırmacıların bulguları arasındaki farklılığın yazlık-kışlık ekim ve çevre koşullarından kaynaklandığı düşünülmektedir.

\section{Tane Verimi}

Denemede topraktan ve yapraktan uygulanan farklı çinko dozlarının yulafın tane verimine etkisine ait ortalama değerler Çizelge 7'de verilmiştir.

Çizelge 5. Çinko dozlarının salkımdaki tane ağırlığına (g) etkisine ait ortalama değerler.

\begin{tabular}{cccccc}
\hline $\begin{array}{c}\text { Yapraktan Zn } \\
\text { Uygulamaları } \\
(\%)\end{array}$ & \multicolumn{5}{c}{ Topraktan Zn Uygulamaları (kg/da) } \\
\hline & 0 & 2.5 & 5 & 7.5 & Ort \\
\hline 0 & 0.55 & 0.43 & 0.50 & 0.40 & 0.47 \\
0.2 & 0.47 & 0.65 & 0.67 & 0.58 & 0.59 \\
0.4 & 0.63 & 0.50 & 0.42 & 0.55 & 0.53 \\
\hline Ortalama & 055 & 0.53 & 0.53 & 0.51 & \\
\hline
\end{tabular}

Çizelge 6. Çinko dozlarının yulafta bin tane ağırlığına (gr) etkisine ait ortalama değerler.

\begin{tabular}{cccccc}
\hline $\begin{array}{c}\text { Yapraktan Zn } \\
\text { Uygulamaları } \\
(\%)\end{array}$ & \multicolumn{5}{c}{ Topraktan Zn Uygulamaları (kg/da) } \\
\hline & 0 & 2.5 & 5 & 7.5 & Ort \\
\hline 0 & 27.21 & 25.93 & 27.35 & 25.23 & 26.43 \\
0.2 & 26.21 & 27.69 & 27.95 & 27.24 & 27.27 \\
0.4 & 26.70 & 28.04 & 26.68 & 26.57 & 26.99 \\
\hline Ortalama & 26.70 & 27.22 & 27.32 & 26.35 & \\
\hline
\end{tabular}

Çizelge 7. Çinko dozların yulafta tane verimine (kg/da) etkisine ait ortalama değerler.

\begin{tabular}{|c|c|c|c|c|c|}
\hline \multirow{2}{*}{$\begin{array}{c}\text { Yapraktan Zn } \\
\text { Uygulamaları } \\
(\%) \\
\end{array}$} & \multicolumn{5}{|c|}{ Topraktan Zn Uygulamaları (kg/da) } \\
\hline & 0 & 2.5 & 5 & 7.5 & Ort \\
\hline 0 & $\begin{array}{c}105.1 \\
8 \mathrm{bc}\end{array}$ & $71.00 \mathrm{e}$ & $\begin{array}{c}76.65 \\
\text { de }\end{array}$ & $\begin{array}{c}75.94 \\
\text { de }\end{array}$ & $82.19 \mathrm{~B}$ \\
\hline 0.2 & $\begin{array}{c}100,0 \\
6 \mathrm{c}\end{array}$ & $96.11 \mathrm{c}$ & $\begin{array}{c}110.51 \\
\mathrm{ab}\end{array}$ & $80.67 \mathrm{~d}$ & $96.84 \mathrm{~A}$ \\
\hline 0.4 & $\begin{array}{c}110.1 \\
5 \mathrm{ab}\end{array}$ & $\begin{array}{c}115.05 \\
\mathrm{a}\end{array}$ & $81.33 \mathrm{~d}$ & $98.33 \mathrm{c}$ & $\begin{array}{c}101.21 \\
\mathrm{~A}\end{array}$ \\
\hline Ortalama & $\begin{array}{c}105.1 \\
3 \mathrm{~A}\end{array}$ & $94.05 \mathrm{~B}$ & $\begin{array}{c}89.49 \\
\text { BC }\end{array}$ & $84.98 \mathrm{C}$ & \\
\hline
\end{tabular}

LSD (Toprak): 5.406; LSD(Yaprak):4.682; LSD (Yaprak x

Toprak): 9.365

Çizelge 7'de görüldüğü gibi, uygulanan farklı çinko dozları ve uygulama şekilleri ile topraktan ve yapraktan uygulanan çinko dozları interaksiyonunun tane verimine etkisi istatistiksel olarak $(\mathrm{P}<0.01)$ önemli bulunmuştur. Yapılan çalışmada tane verimi $71.00 \mathrm{~kg} / \mathrm{da}$ ile $115.05 \mathrm{~kg} / \mathrm{da}$ arasında değişim göstermiştir. Tane verimi en fazla \% 0.4 yapraktan, $2.5 \mathrm{Zn} / \mathrm{da}$ topraktan; \% 0.2 yapraktan, $5.0 \mathrm{~kg} / \mathrm{da}$ topraktan ve \% 0.4 yapraktan, topraktan çinko uygulamasız kombinasyonlardan elde edildiği görülmüştür. En düşük tane verimi ise topraktan 2.5 $\mathrm{kg} / \mathrm{da}$ çinko uygulaması ile yapraktan \% 0 çinko uygulaması interaksiyonundan elde edilmiştir (Çizelge 7). Genel olarak değerlendirildiğinde yapraktan artan dozlarda çinko uygulamalarının verimi artırdığı görülürken, topraktan artan dozlarda çinko uygulamalarının verimi düşürdüğü görülmüştür. Konuyla ilgili Shivay ve ark., (2013) yulaf bitkisinde, Ahmad ve ark., (2018); Nazar, (2012); Zou ve ark., (2012); Kaya ve ark., (2005); Gültekin ve ark., (2004); buğdayda bulgularımıza benzer şekilde çinko uygulamalarının verimi artırdığını belirtmişlerdir. Bununla birlikte Barut ve ark., (2017) ile Aktaş, (2016) buğday da çinko uygulamalarının verim artışında herhangi bir etkisinin olmadığını bildirmişlerdir. Araştırmacıların bulguları arasındaki farklılığın çevre koşullarından ve yazlık-kışlık ekimden kaynaklandığı sanılmaktadır. Çalışmamıza ait bulgularımıza bakıldığında genel olarak tane verimlerinin düşük olduğu görülmektedir. Keza kuraklık ve yüksek sıcaklık, vejetasyon süresi boyunca birbirini takip eden farklı fenolojik dönemler ile bu dönemlerdeki morfolojik ve fizyolojik özelliklerlerin etkileşimleri, metrekarede başak sayısı, bin tane ağırlığı, başakta tane ağırlığı, gibi faktörler tane verimini etkileyen en önemli nedenlerdendir (Öztürk ve Akten, 1999; Leilah ve Al-Khateeb, 2005; Tamm, 2003). Bu bağlamda fenolojik dönemler ile bu dönemlerdeki morfolojik ve fizyolojik özellikler ile çevre faktörlerinin etkisi, bulgularımızda tane verimi değerlerinin düşük olmasına sebep olduğu düşünülmektedir.

\section{Sonuç ve Öneriler}

Araştırma farklı çinko dozları ve uygulama yöntemlerinin yulaf (Avena sativa L.) bitkisinin, bitkisel özelliklerine etkisinin belirlenmesi amacıyla 2017 yılı ilkbahar-yaz döneminde Ordu Üniversitesi Ziraat Fakültesi deneme tarlalarında yürütülmüștür. Çalışmada bitki boyu, salkım boyu, salkımda başakcık sayısı, salkımda tane sayısı, salkımda tane ağırlığı, bin tane ağırlığı ve tane verimi gibi özellikler incelenmiştir. Denemede, farklı çinko dozları ve uygulama şekillerinin salkımda başakcık sayısına, salkımda tane sayısına ve tane verimine etkisi istatiksel olarak önemli, bitki boyu, salkım boyu, salkımda tane ağırlığı ve bin tane ağırlığına etkisi ise önemsiz bulunmuştur. Yapılan uygulamarda salkımda başakçık sayısı, 13.09-25.80 adet arasında salkımda tane sayısı 28-47 adet arasında ve tane, 
verimi 71-115 $\mathrm{kg} / \mathrm{da}$ arasında değișmiș ve istatistiksel olarak önemli çıkmıştır. En fazla başakçık sayısı topraktan $7.5 \mathrm{~kg} \mathrm{Zn} / \mathrm{da}$ ve yapraktan $\% 0.4$ çinko uygulamasından ve en fazla salkımda tane sayısı çinko uygulamasız ve topraktan $7.5 \mathrm{~kg}$ $\mathrm{Zn} /$ da ve yapraktan \% 0.2 çinko uygulamasından elde edilmiştir. En fazla tane verimi ise \% 0.4 yapraktan, $2.5 \mathrm{Zn}$ /da topraktan; \% 0.2 yapraktan, 5.0 $\mathrm{kg} / \mathrm{da}$ topraktan ve \% 0.4 yapraktan, topraktan çinko uygulamasız kombinasyonlardan elde edildiği görülmüştür. Öte yandan istatiskiksel olarak önemli olmamakla birlikte, bitki boyu 70-80 cm arasında, salkım boyunun ise $17-22 \mathrm{~cm}$ arasında, salkımda tane ağırlığı, 0.40-0.67 g arasında ve bin tane ağırlığl, 25-43 g arasında değiştiği tespit edilmiştir. Yapılan çalışma sonucunda, yulaf bitkisine çinko dozları ve uygulama yöntemlerinin belirlenmesinde bir yllık çalışmanın yeterli olamayacağı, ayrıca özellikle yazlık ekimlerde çinkolu gübrelemenin yulaf birkisine etkisinin belirgin bir şekilde belirlenemediği kanaatine varılmıștır. Bu bağlamda bu tür çalışmaların birkaç yıl daha devam etmesi ayrıca kışlık ekimlerde de denenmesinin daha doğru sonuçlara ulaşılacağı düşünülmektedir.

\section{Kaynaklar}

Ahmad, W., Tahir, M., Ahmad, R., \& Ahmad, R. (2018). Agronomic biofortification of fodder sorghum with zinc under different levels of nitrogen. Sains Malaysiana, 47(6), 1269-1276.

Aktaş, H. (2016). Çinko uygulamasının makarnalık buğdayın (Triticum durum desf.) verim ve bazı kalite özellikleri üzerindeki etkisi. Tarla Bitkileri Merkez Araștırma Enstitüsü D., 25(2), 193-201.

Anonim (2003). Gübre Sanayi, TEAE-BAKIŞ, sayı 2, nüsha 3, Mart 2003.

Anonim (2012). https://turktob.org.tr/tr/yulaf-uretimive-yetistiriciligi/4910. Erişim tarihi 25.04.2019

Anonim (2015). Ulusal Hububat Konseyi. www.uhk.org.tr Erişim tarihi: 01.03.2019

Anonim (2019a) Food and Acriculture Organization United Nations. Erişim tarihi, 05.03.2019

Anonim (2019b) Türkiye İstatistik Kurumu. www.tuik.gov.tr Erişim tarihi: 02.03.2019

Barut, H., Şimşek, T., \& Aykanat, S. (2017). Çinko uygulamasının makarnalık buğday çeşitlerinde verim ve bazı tarımsal özellikler üzerine etkisi. Türkiye Tarımsal Araştırmalar Dergisi, 4(1), 10-23.

Bouyoucous, G. L. (1951). A Recalibration of Hydrometer Method for Making Mechanical Analysis of Soils. Agronomy Journal. (43):434-438.
Bremner, J.M. (1965). Total Nitrogen Methods Of Soil Analysis. Part 2. Chemical and Microbiological Properties. Ed. C.A. Black. Amer. Soc. Of Agron. Inc. Pub. Agron. Series. No: 9, Madison, Wisconsin, U.S.A. 1149-1178.

Castagnara, D. D., Krutzmann, A., Zoz, T., Steiner, F., Conte e Castro, A. M., Neres, M. A., \& Oliveira, P. S. R. D. (2012). Effect of boron and zinc fertilization on white oats grown in soil with average content of these nutrients. Revista Brasileira de Zootecnia, 41(7), 1598-1607.

Coleman, J. E. (1992). Zinc proteins: enzymes, storage proteins, transcription factors, and replication proteins. Annual review of biochemistry, 61(1), 897946.

Çakmak, İ. (2000). Tansley Review No. 111 Possible roles of zinc in protecting plant cells from damage by reactive oxygen species. The New Phytologist, 146(2), 185-205.

Dülgerbaki, T. (2010). Maş fasulyesinde (Phaseolus aureus L.) farklı çinko uygulamalarının verim ve verim unsurları üzerine etkisi. Yüksek Lisans. Süleyman Demirel Üniversitesi Fen Bilimleri Enstitüsü Tarla Bitkileri Ana Bilim Dalı, Isparta.

Ekiz, H., Öztürk, L., Bağcl, S.A., Gültekin, İ., Yılmaz, A., \& Çakmak, İ. (1998). Çinko noksanlığının buğdayın kuraklık toleransı üzerine etkileri. I. Ulusal Çinko Kongresi, 12-16 Mayıs, Eskişehir, s. 511-517.

Eyüpoğlu, F., Kurucu, N., Talaz, S., \& Canisağ, U. (1994). Türkiye topraklarının bitkiye yarayışlı mikro element durumu. Toprak ve Gübre Araştırma Enstitüsü Yıllık Raporu, (118), 25-32.

Graham, R. D., Ascher, J. S., \& Hynes, S. C. (1992). Selecting zinc-efficient cereal genotypes for soils of low zinc status. Plant and Soil, 146(1-2), 241-250.

Gültekin, İ., Yılmaz, A., Ekiz, H., Arısoy, R., \& Eker, S. (2004). Çinko demir ve bakır uygulamalarının orta anadolu bölgesinde yetiştirilen buğday verimine etkileri. 3. Ulusal Gübre Kongresi s, 553-562

Hışır, Y., Kara, R., \& Dokuyucu, T. (2012). Evaluation of oat genotypes for grain yield and physiological traits. Zemdirbyste Agriculture, 99(1), 55-60.

Hızalan, E., \& Ünal, H. (1966). Topraklarda önemli kimyasal analizler. AÜ Ziraat Fakültesi Yay., 278.

Jackson, M. L. (1958). Soil Chemical Analysis. Prentice Hall, Englewood Cliffs, New Jersey, USA.

Kalayci, M., Torun, B., Eker, S., Aydin, M., Ozturk, L., \& Cakmak, I. (1999). Grain yield, zinc efficiency and zinc concentration of wheat cultivars grown in a zinc-deficient calcareous soil in field and greenhouse. Field Crops Research,63(1), 87-98. 
Kaya, M., Atak, M., Çiftçi, C. Y., \& Ünver, S. (2005). Çinko ve humik asit uygulamalarının ekmeklik buğday'da verim ve bazı verim öğeleri üzerine etkileri. Süleyman Demirel Üniversitesi.Fen Bilimleri Enstitüsü Dergisi, 9(3), 1-8.

Leilah, A. A., \& Al-Khateeb, S. A. (2005). Statistical analysis of wheat yield under drought conditions. Journal of Arid environments, 61(3), 483-496.

Lindsay, W. L., \& Norvell, W. L. (1978). Development of DTPA Soil Test for Zinc, İron, Manganese, Copper. Soil. Sci. Soc. Am.1978;42:421-428.

Marschner, H. (1995). Mineral Nutrition of Higher Plants (Second Edition) ISBN: 978-0-12-473542-2

Maas, E. V. (1986). Salt Tolerance Of Plants. Applied Agricultural Research. 1986;1:12-26.

Mishra, S.S., Gulati, J.M.L., Nanda, S.S., Garyanak, L.M., \& Jenz, S.N. (1989). Micronutrient studies in wheat. Orissa Journal of Agricultural Research, 22(2): 94 96.

Nazar, H. (2012). Ekmeklik buğdayda (Triticum aestivum L.) farklı besin maddesi içerikteki yaprak gübrelerinin verim, verim öğeleri ve bazı kalite özelliklerine etkisinin belirlenmesi (Master's thesis, Adnan Menderes Üniversitesi, Fen Bilimleri Enstitüsü).

Nelson, D.W., \& Sommers, L.E. (1982). Total Carbon, Organic Carbon and Organic Matter. In 'Methods of analysis. Chemical and microbiological propertise. 539-580.

Öktem, A. G., Coşkun, M., Almaca, N. D., Öktem, A., Söylemez, S., Tekgül, Y. T., \& Sürücü, A. (2016). Şanlıurfa-Ceylanpınar koşullarında yetiştirilen yerli kırmızı mercimek çeşidine farklı miktarlarda uygulanan çinkonun verim ve verim unsurlarına etkisi. Tarla Bitkileri Merkez Araştırma Enstitüsü Dergisi, 25(1), 225-231.

Özbek, V., \& Özgümüş, A. (1997). Farklı çinko uygulamalarının değişik buğday çeşitlerinin verim ve bazı verim kriterleri üzerine etkileri. I. Ulusal Çinko Kongresi, 12-16.

Özcan, H., \& Taban, S. (2012). Effect of zinc application on yield and grain zinc, phosphorus and phytic acid concentration of some rice genotypes. Toprak $\mathrm{Su}$ Dergisi, 1(1), 7-14.

Öztürk, M. (2009). Bazı kışlık yem bitkilerinde çinkolu gübrelemenin verim ve kalite üzerine etkileri. Yüksek Lisans Tezi. Adnan menderes Üniversitesi Fen Bilimleri Enstitüsü Toprak ABD, Aydın.

Öztürk, A., \& Akten, Ş. (1999). Kışlık buğdayda bazı morfofizyolojik karakterler ve tane verimine etkileri. Agriculture and Forestry, 23(2), 409-422.

Richard, L. A. (1954). Diagnosis and Improvement of Saline and Alkali Soils. Agriculture Handbook, No: 60, U. S.
Department of Agriculture. U. S. Grovement Priting Office, Washington D. C.

Sayed, E., Gheith, M.S., \& El-Badry, O.Z. (1988). Effects of the dates of zinc application on wheat. Beyrage Zur Tropischen Landwirtshof und Veterinormadizin, 26(3): 273-278.

Shivay, Y. S., Prasad, R., \& Pal, M. (2013). Zinc fortification of oat grains through zinc fertilisation. Agricultural Research, 2(4), 375-381.

Sonkaya, M. C. (2017). Bazı çeltik (Oryza Sativa L.) çeşitlerinde çinkonun verim, verim öğeleri ve kaliteye etkilerinin belirlenmesi (Yüksek lisanz tezi, Ordu Üniversitesi Fen Bilimleri Enstitüsü).

Sönmez, F., \& Kıral, A. S. (2004). Çinkonun iki ekmeklik buğday (Triticum aestivum L.) çeşitlerinde verim ve bazı verim öğelerine etkisi. Türkiye 3. Ulusal Gübre Kongresi, Tarım-Sanayi-Çevre Kitabı 1.Cilt. 11-13 Ekim, Tokat

Tamm, I. (2003). Genetic and environmental variation of grain yield of oat varieties. Agronomy Research, 1(1), 93-97.

Watanable, F. S., \& Olsen, S.R. (1965). Test of an Ascorbic Acid Method for Determining Phosphorus in Water and NaHCO3 Extracts from Soil. Soil Sci. Soc. Am. Proc. (29): 677-678.

Welch, R. M. (1993). Zinc in Soils and Plants. Volume 55 of the series Developments in Plant and Soil Sciences pp 183-195

Yalçın, S. R. \& Usta, S. (1992). Çinko Uygulamasının Mısır Bitkisinin Gelişmesi ile Çinko, Demir, Mangan ve Bakır Kapsamları Üzerine Etkisi. A. Ü. Ziraat Fakültesi Yıllı̆̆ı, Cilt 4: 1-2, 195-204.

Yılmaz A., Ekiz H., Torun, B., Gültekin, I., Karanlık, S., Bağcı, S. A., \& Çakmak, I. (1997). Effect of different zinc application methods on grain yield and zinc concentration in wheat grown on zinc-deficient calcareous soils in Central Anatolia. J Plant Nutr 20:461-471.

Yılmaz, N., \& Sonkaya, M.C. (2017). Bazı Çeltik (Oryza sativa L.) Çeşitlerinde Çinkonun Agronomik ve Morfolojik Özelliklerine Etkilerinin Belirlenmesi. İnternational Advanced Research and Engineering Congres. 16-18 November 2017 Osmaniye.

Zou, C. Q., Zhang, Y.Q., Rashid, A., Ram, H., Savasli, E., Arisoy, R. Z., Ortiz-Monasterio, I., Simunji, S., Wang, Z. H., Sohu, V., Hassan, M., Kaya, Y., Onder, O., Lungu, O., Mujahid, M. Y., Joshi, A. K., Zelenskiy, Y., Zhang, F., S, \& Cakmak, I. (2012). Biofortification of wheat with zinc through zinc fertilization in seven countries. Plant Soil 361: 119 - 130. 